Article

\title{
Concentrations and Fractionation of Carbon, Iron, Sulfur, Nitrogen and Phosphorus in Mangrove Sediments Along an Intertidal Gradient (Semi-Arid Climate, New Caledonia)
}

\author{
Jonathan Deborde ${ }^{1}$, Cyril Marchand ${ }^{1, *}$, Nathalie Molnar ${ }^{1,2}$, Luc Della Patrona ${ }^{3}$ \\ and Tarik Meziane ${ }^{2}$
}

1 Institut de Recherche pour le Développement (IRD), UR 206, UMR 7590-IMPMC, F-98848 New Caledonia, France; E-Mails: jonathan.deborde@gmail.com (J.D.); nathaliemolnar@gmail.com (N.M.)

2 UMR BOREA 7208 CNRS-MNHN-UPMC-IRD-UCBN, Muséum National Histoire Naturelle, CP 53, 61 rue Buffon, 75231 Paris cedex 05, France; E-Mail: meziane@mnhn.fr

3 Département Lagons, Ecosystèmes et Aquaculture Durable (LEAD/NC), Ifremer, 101, Promenade Roger Laroque, Center IRD, BP 2059-98846 Nouméa Cedex, Nouvelle-Calédonie;

E-Mail: Luc.Della.Patrona@ifremer.fr

* Author to whom correspondence should be addressed; E-Mail: cyril.marchand@ird.fr; Tel.: +33637081531 .

Academic Editors: Joseph M. Smoak and Christian Joshua Sanders

Received: 2 November 2014 / Accepted: 4 February 2015 / Published: 10 February 2015

\begin{abstract}
In mangrove ecosystems, strong reciprocal interactions exist between plant and substrate. Under semi-arid climate, Rhizophora spp. are usually predominant, colonizing the seashore, and Avicennia marina develops at the edge of salt-flats, which is the highest zone in the intertidal range. Along this zonation, distribution and speciation of $\mathrm{C}, \mathrm{Fe}, \mathrm{S}, \mathrm{N}$, and $\mathrm{P}$ in sediments and pore-waters were investigated. From the land-side to the sea-side of the mangrove, sediments were characterized by I/ increase in: (i) water content; (ii) TOC; (iii) mangrove-derived OM; II/ and decrease in: (i) salinity; (ii) redox; (iii) $\mathrm{pH}$; (iv) solid Fe and solid P. Beneath Avicennia and Rhizophora, TS accumulated at depth, probably as a result of reduction of iron oxides and sulfate. The loss of total $\mathrm{Fe}$ observed towards the sea-side may be related to sulfur oxidation and to more intense tidal flushing of dissolved components. Except the organic forms, dissolved $\mathrm{N}$ and $\mathrm{P}$ concentrations were very low
\end{abstract}


beneath Avicennia and Rhizophora stands, probably as a result of their uptake by the root systems. However, in the unvegetated salt-flat, $\mathrm{NH}_{4}{ }^{+}$can accumulate in organic rich and anoxic layers. This study shows: (i) the evolution of mangrove sediment biogeochemistry along the intertidal zone as a result of the different duration of tidal inundation and organic enrichment; and (ii) the strong links between the distribution and speciation of the different elements.

Keywords: mangrove; zonation; biogeochemistry; New Caledonia

\section{Introduction}

Mangroves are the dominant ecosystems of tropical and subtropical coastlines, covering nearly $140,000 \mathrm{~km}^{2}$ [1]. Beyond their ecological, sociological, and economical roles [2-4], mangroves are of great interest for the study of biogeochemical cycles, notably because of marine and fresh water mixing, and because large amount of carbon accumulation [5,6]. Pathways of organic matter decomposition in mangrove sediments are diverse, from aerobic respiration to anaerobic sulfate reduction, through denitrification, manganese respiration and iron respiration, leading to a high variability of elements distribution and speciation [7]. In addition to the quality and the quantity of organic inputs, sedimentation rates, and biological activities, other parameters have to be taken into account to understand mangrove sediments biogeochemistry, e.g., the tree species and their age, tides and bioturbation [8-11]. Additionally, strong interactions between mangrove plants and substrate geochemistry were demonstrated, resulting in the zonation of the ecosystem [12-14]. Extension, secretion and absorption of nutrients by the root system, as well as the oxygenation capacity of the soil, are characteristic of each plant species [10,15]. Consequently, concentration and fractionation of major elements may depend on mangrove stands. In New-Caledonia, mangrove forests are developed over 35,000 ha, fringing on about $80 \%$ and $15 \%$ of the western and the eastern coastline of the island, respectively [16]. Previous studies $[17,18]$ suggested that the main factor controlling the distribution of mangrove species in New Caledonia was soil salinity, which in turn was controlled by the duration of tidal inundation and thus by the soil elevation [19]. Thus, our hypothesis are that towards the sea-side: (i) the sediment will be enriched in organic matter because of higher productivity resulting from less stressing conditions; (ii) the sediments will be more reducing because of longer waterlogging and higher organic content; (iii) and the concentrations of key nutrients will be lower because of plant uptake. The main objective of the present study was to understand how the distribution of the different mangrove vegetation along the intertidal zone may influence the distribution and the speciation of $\mathrm{C}, \mathrm{N}, \mathrm{P}, \mathrm{Fe}$, and $\mathrm{S}$ in mangrove sediments and pore-waters.

\section{Material and methods}

\subsection{Study Site}

Mangroves in New Caledonia are dominated by Rhizophora spp. (55\% of the total mangrove area), and Avicennia marina (14\%). Salt-flat represents $26 \%$ of the total mangrove area. The study was conducted in a fringing mangrove located in Saint Vincent Bay, New Caledonia (Figure 1). This mangrove 
$\left(21^{\circ} 54^{\prime} \mathrm{S}, 166^{\circ} 04^{\prime} \mathrm{E}\right)$, covering 20 ha, does not receive any significant freshwater runoff, and was free of anthropogenic influences. This forest exhibits the typical zonation of mangroves in New Caledonia [18]: (i) at the back side of the mangrove swamp, the area is occupied by the salt-flat, a highly saline zone, only submerged during high spring tide and covered sporadically in the most downstream stretches with bushes of Sarcocornia quinqueflora; (ii) a second stand of vegetation, downstream, is occupied by Avicennia marina; (iii) finally, the seaward edge is occupied by Rhizophora stylosa, which is submerged at each tide. Tides are semidiurnal, and mangroves were fully drained at each low tide, except during neap tides where parts of the Rhizophora area remain flooded. The landward Avicennia was sparsely distributed, bush-like and never exceeded $1 \mathrm{~m}$ in height. The seaward Rhizophora zone had a relatively low density and individual trees rarely exceeded $3 \mathrm{~m}$ in height. Fiddler crabs, Uca spp., were present in the salt-flat and Avicennia stands with high density of burrows. Density was estimated using photography of sampling sites, and was about 20 and 30 burrows $\cdot \mathrm{m}^{-2}$ for the salt-flat and Avicennia, respectively. In the Rhizophora forest, the main crab specie present was a Grapsidae with an estimate density of about 40 burrows $\cdot \mathrm{m}^{-2}$. Three sampling sites were chosen corresponding to the three vegetation stands (Figure 1).

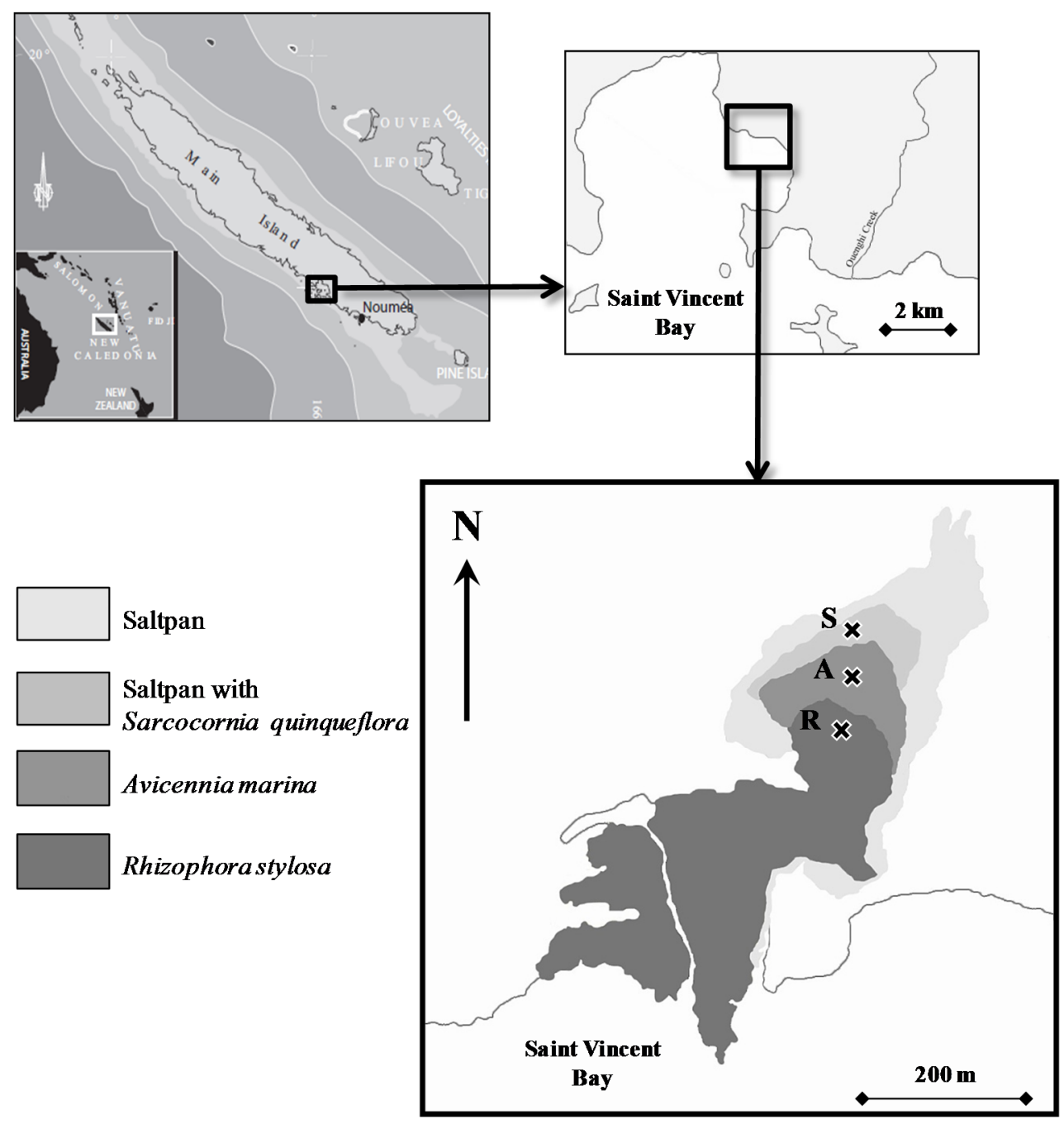

Figure 1. Map showing the location of the studied mangrove in Saint Vincent Bay on the west coast of New Caledonia, with vegetation zonation and the location of sampling sites in: (S) Salt-flat with Sarcocornia quinqueflora, (A) Avicennia marina and (R) Rhizophora stylosa. 


\subsection{Sampling Collection}

Sediment cores $(50 \mathrm{~cm})$ were collected in June 2009. Considering the low tidal range in New Caledonia, this sampling depth allowed us to reach the redox boundary between the unsaturated zones (evolving with tides) and the saturated zone. In addition, we were interested in the possible role of the root system; the latter mainly develop in the upper $50 \mathrm{~cm}$ considering the limited development of trees in this semi-arid climate. Cores were sampled in triplicate during low tide using an Eijkelkamp gouge auger in each mangrove stand. Core locations were chosen close to the vegetation but carefully avoiding the presence of main roots in samples. After being collected, cores were wrapped in plastic film and aluminum foil to prevent oxidation and photo-oxidation, and were transported to an air conditioned laboratory within $10 \mathrm{~min}$. Samples were collected every $5 \mathrm{~cm}$ from 0 to $50 \mathrm{~cm}$ depth. Sediment sub-samples were taken and immediately sealed in a pre-weighed vial, and frozen for analyses of Fe and $\mathrm{P}$ solid fractions, and water content determination. A second sediment sub-sample was taken and was freeze-dried for analyses of total organic carbon (TOC), organic matter characterization (stable isotope composition: $\delta^{13} \mathrm{C}$ and $\delta^{15} \mathrm{~N}$ ) and total sulfur (TS). Pore-waters were collected using soil moisture samplers Rhizon $^{\circledR}$ (Eijkelkamp Agrisearch Equipment, Giesbeek, The Netherlands) [20,21]. This method allowed us to extract $20 \mathrm{~mL}$ from $5 \mathrm{~cm}$ long sediment section. After filtration through $45 \mu \mathrm{m}$ cellulose acetate syringe-filter, one aliquot was acidified with $\mathrm{HNO}_{3}$ and store refrigerated for $\mathrm{Fe}$ analysis $\left(\mathrm{Fe}^{2+}\right.$ and $\left.\mathrm{Fe}^{3+}\right)$, a second was frozen at $-25^{\circ} \mathrm{C}$ for nutrient analysis $\left(\mathrm{NH}_{4}^{+}, \mathrm{NOx}, \mathrm{DON}\right.$; DIP, DOP).

\subsection{Analytical Methods}

\subsubsection{Salinity, $\mathrm{pH}$, Redox Potential and $\sum \mathrm{H}_{2} \mathrm{~S}$ Measurements}

Salinity, $\mathrm{pH}$, redox and $\sum \mathrm{H}_{2} \mathrm{~S}$ were measured in an air-conditioned laboratory within 30 min after the core sampling [17]. $\mathrm{pH}$ and redox were measured using a WTW $\mathrm{pH} / \mathrm{mV} / \mathrm{T}$ meter. Redox data are reported relative to a standard hydrogen electrode after adding $202 \mathrm{mV}$ to the original $\mathrm{mV}$ values obtained with an $\mathrm{Ag} / \mathrm{AgCl}$ reference electrode at $25^{\circ} \mathrm{C}$. A Wilcoxon-Mann-Whitney (WMW) test was used to compare mean values for pairs (Salt-flat vs. vegetated zone, Rhizophora vs. Avicennia). An Atago manual refractometer was used to determine salinity from pore-water extracted with Rhizon. The determination of the total sulfide concentration (TS, $\mathrm{S}^{2-}, \mathrm{H}_{2} \mathrm{~S}$ and $\mathrm{HS}^{-}$, [22]) was done with a WTW sulfide ion specific electrode $\left(\left(\log \left(\mathrm{S}^{2-}\right)=-0.024 \times \mathrm{E}(\mathrm{V})-0.878\right),[10]\right)$.

\subsubsection{Pore-Water Analysis}

Dissolved iron $\left(\mathrm{Fe}^{2+}\right.$ and $\left.\mathrm{Fe}^{3+}\right)$ were determined by colorimetric procedures with a precision of $\pm 5 \%$ [23,24]. A nephelometric method adapted from [25] was used to determine sulfate (with a precision of about 5\%). $\mathrm{NH}_{4}^{+}$concentrations were measured with a TD700 fluorimeter (TurnerDesigns, Sunnyvale, CA, USA) following the method of Holmes et al. [26]. The method of Bendschneider and Robinson (1952, [27]) was used to determine NOx (nitrate + nitrite) concentrations, using an Autoanalyzer III (Bran+Luebbe, Norderstedt Germany). Dissolved inorganic phosphorus (DIP) concentrations were determined using the autoanalyzer III (Bran+Luebbe, Norderstedt, Germany) [28]. Following a persulfate wet-oxidation in low alkaline condition, total dissolved nitrogen (TDN) and 
phosphorus (TDP) concentrations were determined as NOx and DIP according to the method of Raimbault (1999, [29]). Dissolved organic fractions (DON and DOP) concentrations were calculated by difference between the measured TDN and TDP and the measured inorganic nitrogen $\left(\mathrm{NH}_{4}{ }^{+}\right.$and $\left.\mathrm{NOx}\right)$ and phosphorus (DIP).

\subsubsection{Sediment Solid Phase Analysis}

\subsubsection{Total Organic Carbon, Total Sulfur}

Total organic carbon (TOC), hydrogen index (HI) and oxygen index (OI), were determined using a Rock-Eval 6 pyrolysis [30,31]. Briefly, samples are first pyrolysed under an inert $\mathrm{N}_{2}$ atmosphere and the residual carbon is subsequently burnt in an oxidation oven. The amount of hydrocarbons (HC) released during pyrolysis is detected with a flame ionization detector (FID) (Vinci Technology, Nanterre, France), while online infrared detectors measure continuously the released $\mathrm{CO}$ and $\mathrm{CO}_{2}$. Classical Rock-Eval parameters are calculated by integration of the amounts of $\mathrm{HC}, \mathrm{CO}$ and $\mathrm{CO}_{2}$ produced during thermal cracking of the OM, between well-defined temperature limits. HI corresponds to the quantity of $\mathrm{HC}$ released relative to $\mathrm{TOC}$ (in $\mathrm{mg} \cdot \mathrm{HC} \cdot \mathrm{g}^{-1} \cdot \mathrm{TOC}$ ) and correlating with the $\mathrm{H} / \mathrm{C}$ ratio. OI corresponds to the quantity of oxygen released as $\mathrm{CO}$ and $\mathrm{CO}_{2}$ during pyrolysis, relative to $\mathrm{TOC}$ (in $\mathrm{mg} \cdot \mathrm{HC} \cdot \mathrm{g}^{-1} \cdot \mathrm{TOC}$ ) and correlating with the $\mathrm{O} / \mathrm{C}$ ratio. A CNS-2000 LECO apparatus was used to determine total nitrogen and total sulfur (TS) concentrations (combustion at $1100{ }^{\circ} \mathrm{C}$ ).

\subsubsection{Stable Isotope Analysis}

Sediment samples for stable-isotope analysis $\left(\delta^{13} \mathrm{C}\right.$ and $\left.\delta^{15} \mathrm{~N}\right)$ were freeze-dried before being ground with a mortar. Analysis were made with a PDZ Europa ANCA-GSL elemental analyzer (Sercon Ltd., Cheshire, UK)) interfaced to a PDZ Europa 20-20 isotope ratio mass spectrometer (Sercon Ltd., Cheshire, UK) at the UC Davis Stable Isotope Facility laboratory. After sample combustion at $1000{ }^{\circ} \mathrm{C}$ in a reactor packed with chromium oxide and silvered cobaltous/cobaltic oxide, oxides were removed in a reduction reactor (reduced copper at $650{ }^{\circ} \mathrm{C}$ ). Then, helium carrier flows through a water trap (magnesium perchlorate) and an optional $\mathrm{CO}_{2}$ trap (for N-only analyses). Eventually, $\mathrm{N}_{2}$ and $\mathrm{CO}_{2}$ were separated on a Carbosieve GC column $\left(65^{\circ} \mathrm{C}, 65 \mathrm{~mL} \cdot \mathrm{min}^{-1}\right)$ before entering the IRMS.

\subsubsection{Particulate Iron and Phosphorus Extractions}

The water content of sediments was determined by weight loss after freeze-drying, sea salt correction was applied. Particulate iron and phosphorus extractions were conducted like previously described in Deborde et al. [32]. An ascorbate reagent was added to the dried solid sample to remove the most reactive Fe (III) phases ( $\left.\mathrm{Fe}_{\mathrm{ASC}}\right)$ and the associated phosphorus $\left(\mathrm{P}_{\mathrm{ASC}}\right)$ from the sediment $[33,34]$. Acid-soluble iron $\left(\mathrm{Fe}_{\mathrm{HCl}}\right)$ and phosphorus $\left(\mathrm{P}_{\mathrm{HCl}}\right)$ extraction was carried out with $1 \mathrm{M} \mathrm{HCl}$, which dissolves amorphous Fe oxides, FeS, Fe phyllosilicates and carbonates [34]. $\mathrm{P}_{\mathrm{HCl}}$ originated from detrital and authigenic phosphate minerals, as well as carbonates [34,35]. For both extractions, about $100 \mathrm{mg}$ of dry sample was leached with $10 \mathrm{~mL}$ of solution. Solutions were shaken continuously during $24 \mathrm{~h}$ at room temperature. Samples were centrifuged after extraction, and Fe and P contents of the supernatant were determined 
spectrophotometrically using the ferrozine and molybdate methods. Blank solutions experienced the same treatment. The precision estimated from replicates was $\pm 5 \%$ for $\mathrm{P}$ and $\pm 7 \%$ for Fe.

A)

Sarcocornia quinqueflora

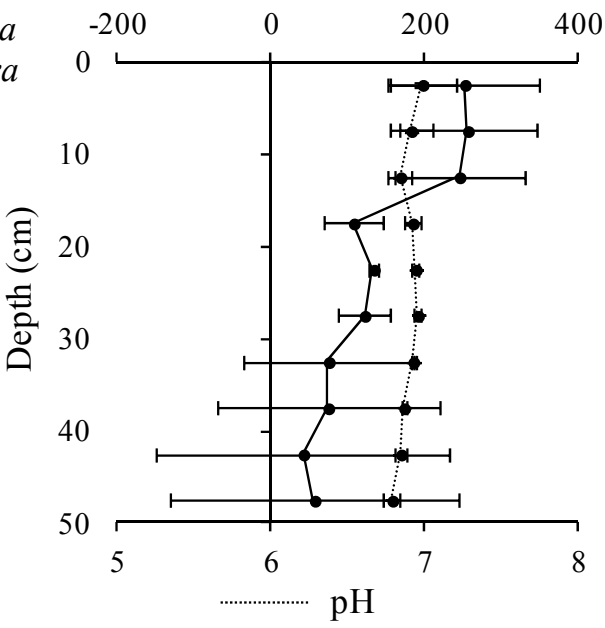

B)

Avicennia
marina

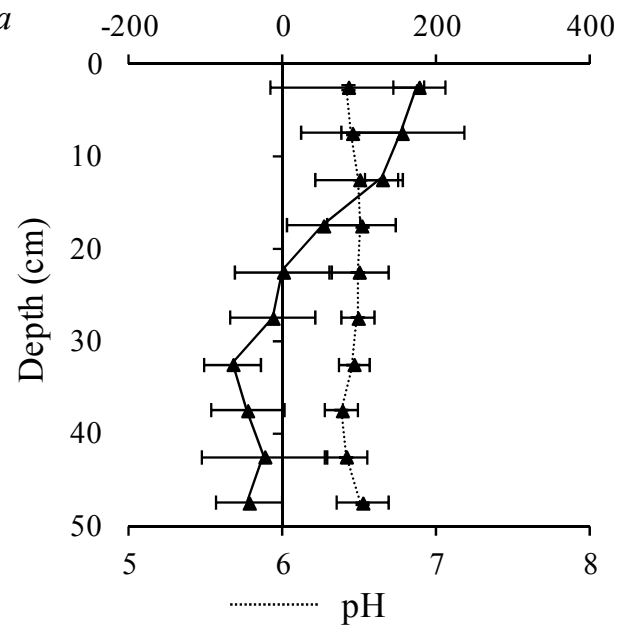

C) Rhizophora
stylosa

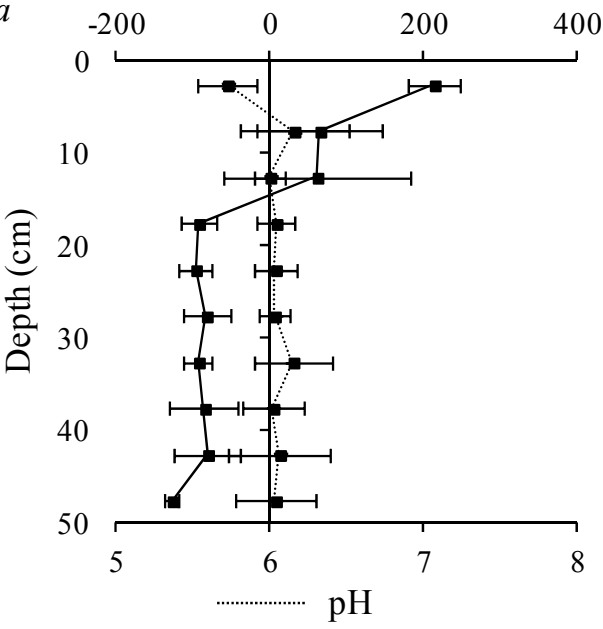

-.--- Salinity

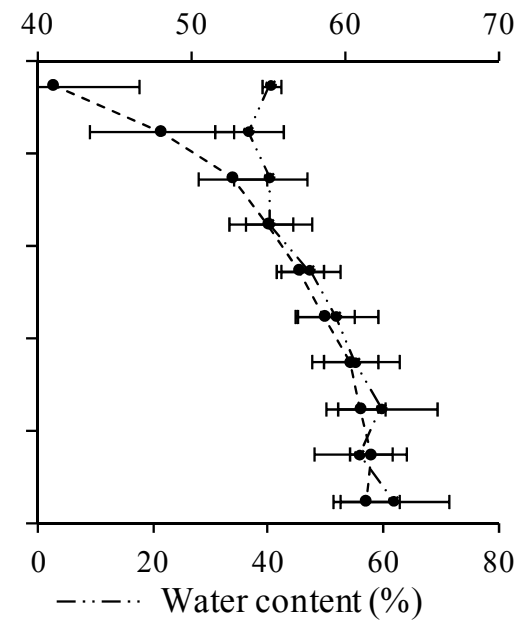

Salinity

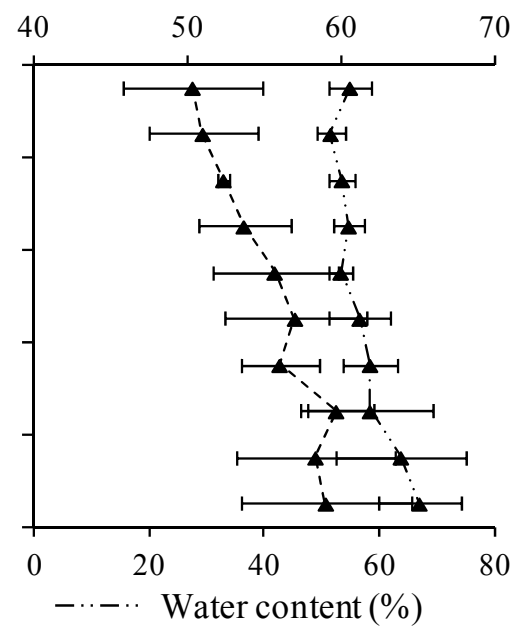

Salinity

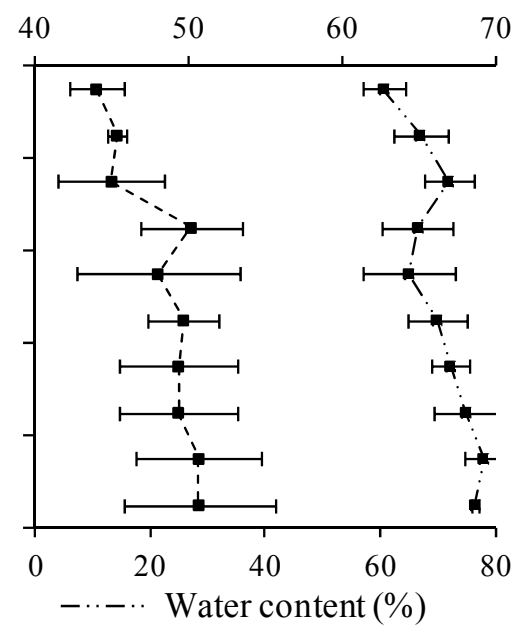

Figure 2. Mean values $(n=3)$ and standard deviation of redox potential, $\mathrm{pH}$, salinity and water content measured in the sediment from surface to $50 \mathrm{~cm}$ depth of the three mangrove vegetation stands. 


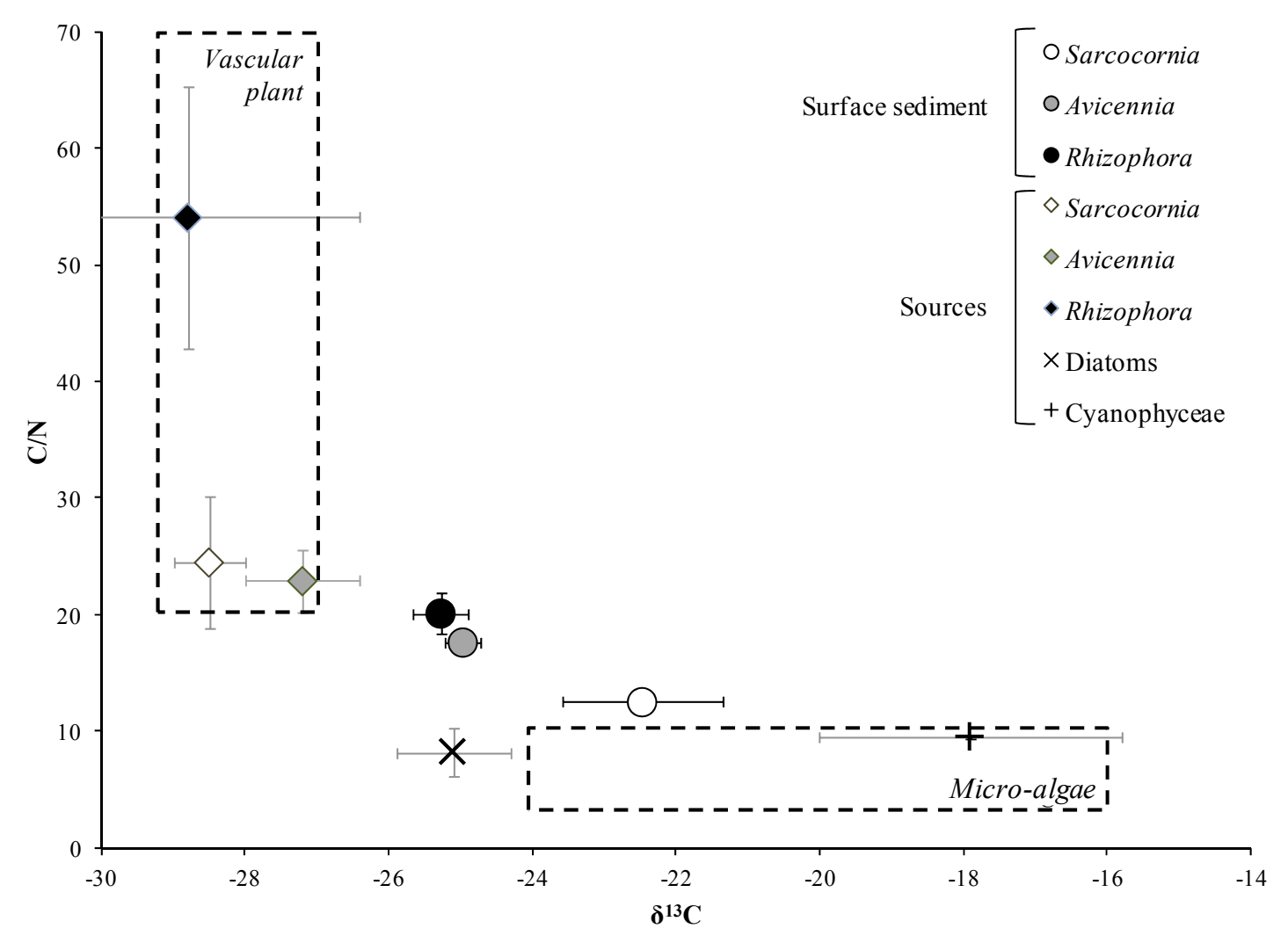

Figure 3. Mean $\mathrm{C} / \mathrm{N}$ and $\delta^{13} \mathrm{C}$ values of surface sediment for each mangrove stand, and values of organic matter source identified in the mangrove. The range of values typically encountered in the literature for vascular mangrove plants (Bouillon et al., 2003, Marchand et al., 2005) and micro-algae (Meyers, 1994) were indicated by the dotted rectangles.

\section{Results and Discussion}

\subsection{Influence of Mangrove Zonation on Sediment Physico-Chemical Properties and Organic Matter Content}

From the salt-flat to the Rhizophora stand, sediment water content increased, with mean values of $49 \% \pm 2 \%$ and $71 \% \pm 3 \%$, respectively, while mean salinity value decreased, from 55 to 42 (Figure $2 a-c$ ). In addition, both parameters increased with depth in every stands, particularly in the salt-flat area, where salinity reached more than 60 . This depth increase may result from convection processes leading to high and stable salinity along the year as suggested by Marchand et al. [10]. The water content and salinity gradients most likely resulted from differences in tidal inundation between stands, which is the main factor controlling mangrove zonation in New Caledonia [17,19]. Pore-water salinity decreased towards the Rhizophora stand, where evaporation processes are limited due to the rare periods of emersions. Mangrove plants have different abilities to cope with pore-water salinity, Avicennia trees are better adapted to high salinities than Rhizophora trees, explaining thus its higher tidal position. However, the energy cost of this adaptation limits the tree development of Avicennia, which only form dwarf stands in New Caledonia. Consequently, we suggest that such a zonation and adaptation may also have an influence on mangrove productivity and thus on organic carbon accumulation in the sediment. $\mathrm{C} / \mathrm{N}$ 
and $\delta^{13} \mathrm{C}$ values of the main organic matter sources are displayed in Figure 3. $\mathrm{C} / \mathrm{N}$ and $\delta^{13} \mathrm{C}$ values were $24.5 \pm 5.6$ and $-28.5 \%$ $\pm 0.5 \%$ for Salicornia, $22.9 \pm 2.7$ and $-27.2 \%$ $\pm 0.8 \%$ for Avicennia, $54.1 \pm$ 11.3 and $-28.8 \% \pm 2.4 \%$ for Rhizophora, respectively. $\mathrm{C} / \mathrm{N}$ values measured for diatoms and cyanophyceae were $8.2 \pm 2.1$ and $9.5 \pm 0.2$, respectively, and their $\delta^{13} \mathrm{C}$ values were $-25.1 \%_{0} \pm 0.8 \%$ and $-17.9 \%_{0} \pm$ $2.1 \%$, respectively. $\mathrm{C} / \mathrm{N}$ and $\delta^{13} \mathrm{C}$ values of the leaves of the two studied mangrove species and Salicornia are consistent with those found in the literature [36,37]. TOC, C/S, HI and OI measured in sediment cores of the different stands are displayed in Figure 4. In the upper sediment, TOC increased from the salt-flat (2\%) to the Rhizophora stand (19\%). Mangrove TOC values usually range between $0.5 \%$ and $15 \%$, with a median TOC around $2.2 \%$ [7]. The sedimentary organic matter has $\mathrm{C} / \mathrm{N}$ and $\delta^{13} \mathrm{C}$ values ranging between those of the leaves and those of micro-algae (Figure 3). Mean $\delta^{13} \mathrm{C}$ value in salt-flat sediments was $-22.5 \%$ $\pm 1.1 \%$, and was lower beneath Avicennia and Rhizophora: $-25 \%$ \pm $0.2 \%$ and $-25.3 \% \neq \pm 0.4 \%$, respectively (Figure 3 ). $\mathrm{C} / \mathrm{N}$ values increased from the land-side to the sea-side of the mangrove: $12.5 \pm 0.6$ beneath Sarcocornia, $17.6 \pm 0.6$ beneath Avicennia, and $20.1 \pm 1.7$ beneath Rhizophora (Figure 3). Consequently, the contribution on mangrove-derived OM to the sedimentary organic pool increased towards the seaside. Due to its low intertidal position, the Rhizophora zone receives more nutrients, which favor both tree development and organic accumulation in sediments. In addition to leaf litter and micro-algae, a strong input of OM derived from root systems was evidenced with the increase of $\mathrm{HI}$ values from surface to mid-depth from 150 to 220, and from 200 to $250 \mathrm{mg} \cdot \mathrm{HC} \cdot \mathrm{g}^{-1} \cdot \mathrm{TOC}$ beneath the Avicennia and the Rhizophora stands respectively. Fresh mangrove tissues are characterized by $\mathrm{HI}$ values ranging from 400 to $600 \mathrm{mg} \cdot \mathrm{HC} \cdot \mathrm{g}^{-1} \cdot \mathrm{TOC}$, and $\mathrm{OI}$ values ranging from 100 to $200 \mathrm{mg} \cdot \mathrm{O}_{2} \cdot \mathrm{g}^{-1}$. TOC [30]. OM decomposition induces its dehydrogenation and oxidation, and thus a decrease of $\mathrm{HI}$ values and an increase of $\mathrm{OI}$ values. In the present study, $\mathrm{HI}$ values ranged between 60 and $230 \mathrm{mg} \mathrm{HC} \cdot \mathrm{g}^{-1} \cdot \mathrm{TOC}$, evidencing that even in the upper sediment, OM was already well decomposed. Higher OI values in the upper layer than at depth may be related to the redox conditions. In fact, the deeper layers were strongly anoxic and $\mathrm{C} / \mathrm{S}$ ratios close to 2 , showing intense sulfuration processes, and thus, probably less efficient oxidation. Eventually, below $30 \mathrm{~cm}$ depth of three studied stands, sediments presented an organic carbon rich layer ( $8 \%$ to $16 \%$ ), characterized by higher $\mathrm{C} / \mathrm{N}$ ratios (29.9 to 41.7) and lower $\delta^{13} \mathrm{C}$ and $\delta^{15} \mathrm{~N}$ values, below -25.2 and 1.8 respectively (Table 1), typical of higher plant debris. These layers were visually enriched with red Rhizophora tissues. This organic-rich sediments may be related to a sudden change in sea level coupled with a massive sedimentary deposit that had buried a former mangrove as previously reported in New Caledonia [18] or in Guadeloupe mangroves [38]. To summarize, in the upper layers from the land-side to the sea-side of the mangrove, the sediment was characterized by gradients in water content, salinity, TOC, and mangrove derived-OM. The gradients above are also associated with redox and $\mathrm{pH}$ values. Redox values decreased from the land-side to the sea-side, and with depth. Within the salt-flat, redox potential was high and stable in the upper $10 \mathrm{~cm}$, with a maximum value of $255 \pm 29 \mathrm{mV}$ that decreased to $60 \mathrm{mV}$ at depth (Figure 2a). Sediments of Avicennia and Rhizophora had significantly lower redox potentials for all depths than the salt-flat (WMW test, $p<0.05$ ), while difference was not significant between Avicennia and Rhizophora sediments (WMW test, $p>0.05$ ). Beneath Rhizophora, redox values decreased rapidly with depth, from $213.9 \pm 13$ to $-92 \pm 18 \mathrm{mV}$. Salt-flat sediments presented the less reducing conditions of the three vegetation stands because of the short tidal inundation associated with desiccation mud cracks that allowed inflow of atmospheric oxygen, and of the presence of crab burrows, which can promote oxygen 
penetration ([39,40], Figure 2). The higher OM concentrations in Avicennia sediments led to lower redox values compare to salt-flat (Figure 2). Nevertheless, suboxic conditions (high redox potential and presence of dissolved iron) remained in the upper $15 \mathrm{~cm}$. These suboxic conditions were favored by the high oxygenation capacity of the radial cable roots of Avicennia [10,12,41], and Uca sp. activity, which were also present in this stand. Within the Rhizophora stand, redox condition became rapidly anoxic with depth due to the high OM content, the high water content, and the low oxygenation capacity of Rhizophora roots [10,41]. Eventually, there was also a gradient of $\mathrm{pH}$ values from the land-side to the sea-side of the mangrove, $6.9 \pm 0.1$ in the Sarcocornia stand (Figure 2a), $6.5 \pm 0.1$ beneath Avicennia (Figure 2b), and $6.0 \pm 0.1$ in the Rhizophora stand (Figure 2c). Acidity of mangrove sediments can derive from organic matter decomposition, TOC concentrations increasing towards the sea, and/or sulfide oxidation (see next chapter).

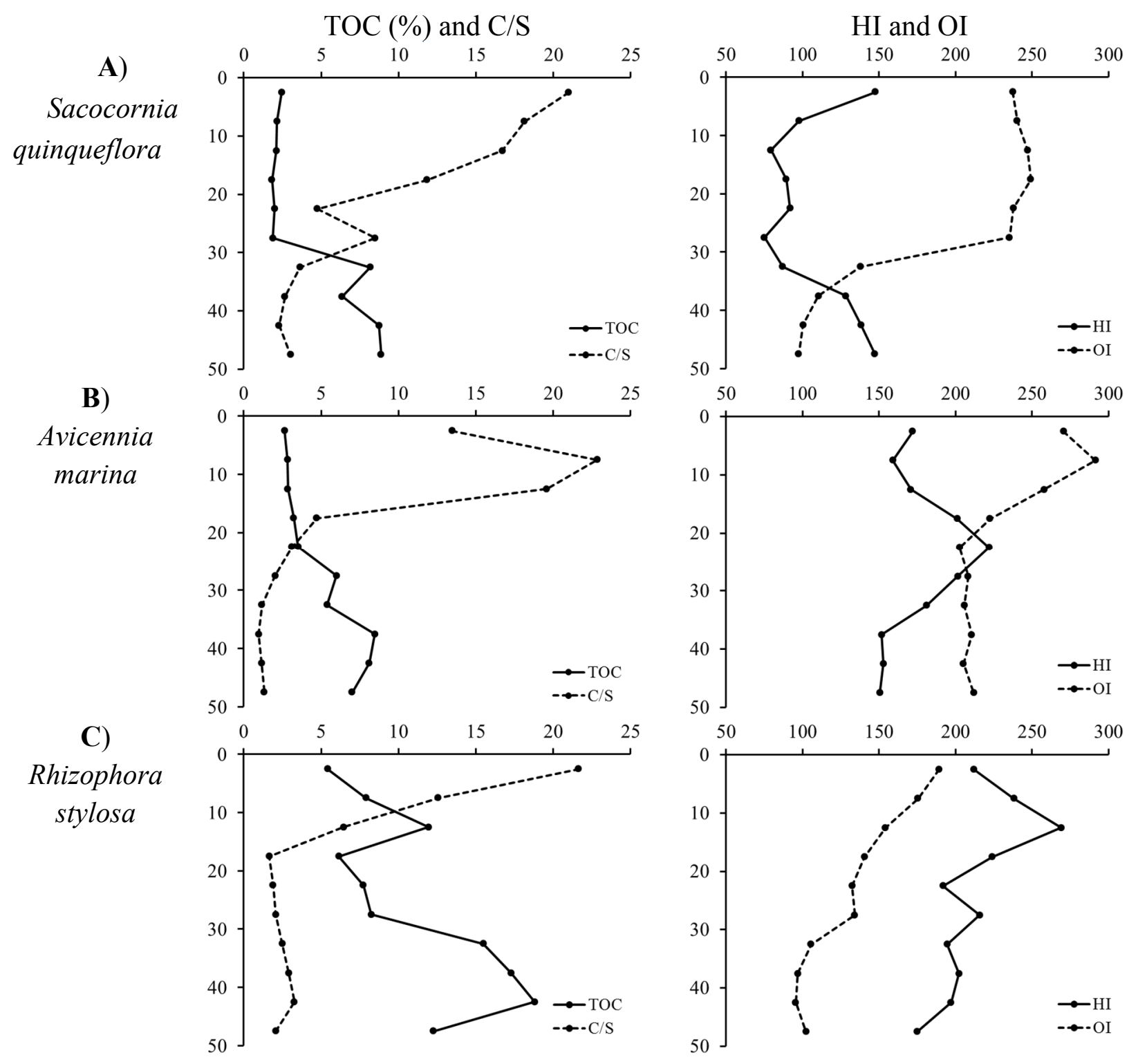

Figure 4. Total Organic Carbon (TOC\%), Hydrogen Index (HI), C/S Ratios and Oxygen Index (OI) values in sediments of the three vegetation stands. 
Table 1. Mean $\mathrm{C} / \mathrm{N}$ ratios, $\delta^{13} \mathrm{C}$ and $\delta^{15} \mathrm{~N}$ values of sediments in Avicennia marina stand. Standard deviations are indicated in italics. (Isotopic data were not available for sediments collected beneath the salt-flat and the Rhizophora stand).

\begin{tabular}{ccccccc}
\hline Depth (cm) & \multicolumn{2}{c}{ C/N } & \multicolumn{2}{c}{$\boldsymbol{\delta}^{\mathbf{1 3}} \mathbf{C}$} & \multicolumn{2}{c}{$\boldsymbol{\delta}^{\mathbf{1 5}} \mathbf{N}$} \\
\hline & & $\boldsymbol{S D}$ & & $\boldsymbol{S D}$ & & $\boldsymbol{S D}$ \\
\hline $0-5$ & 12.4 & 1.5 & -23.3 & 1.1 & 2.8 & 0.8 \\
$5-10$ & 14.7 & 1.1 & -24.1 & 0.2 & 2.3 & 0.1 \\
$15-20$ & 16.4 & 2.1 & -23.9 & 0.2 & 2.0 & 0.5 \\
$30-35$ & 29.9 & 8.8 & -25.2 & 1.1 & 1.8 & 0.4 \\
$40-45$ & 41.7 & 12.5 & -26.1 & 0.6 & 1.7 & 0.2 \\
\hline
\end{tabular}

\subsection{Distribution and Speciation of Redox Sensitive Elements: Iron and Sulfur}

Total iron $\left(\mathrm{Fe}_{\mathrm{ASC}}+\mathrm{Fe} \mathrm{HCl}\right)$ decreased from the salt-flat to the Rhizophora stand. In the sediments of the Avicennia and Rhizophora stands, $\mathrm{Fe}_{\mathrm{ASC}}$ and $\mathrm{Fe}_{\mathrm{HCl}}$ concentrations showed the same trend: decreasing from the top to mid-depth, and then slightly increasing, especially in the ascorbate fraction below $30 \mathrm{~cm}$ deep. Total iron concentrations in sediments of the salt-flat were very high in the upper $30 \mathrm{~cm}$ reaching $123 \pm 106 \mu \mathrm{mol} \cdot \mathrm{g}^{-1}$ for $\mathrm{Fe}_{\mathrm{ASC}}$ and $232 \pm 83 \mu \mathrm{mol} \cdot \mathrm{g}^{-1}$ for Fe $\mathrm{HCl}$ (Figure 5a). In New Caledonia, mangroves act as a barrier between the largest lagoon in the world and lateritic soils exploited for their richness in trace metals, mainly $\mathrm{Ni}$ and $\mathrm{Cr}$. Lateritic soils are primarily composed of $\mathrm{Fe}$ (III)-bearing goethite and phyllosilicates [42]. The mangrove studied here does not develop downstream an ultramafic watershed. However, due to coastal current [43], some of these minerals may have been deposited in the mangrove, explaining the high concentrations of Fe measured in the solid phase. Within the salt-flat, reduced dissolved iron $\left(\mathrm{Fe}^{2+}\right)$ was very low $\left(<8 \mu \mathrm{mol} \cdot \mathrm{L}^{-1}\right)$ on the whole depth profile, while in Avicennia and Rhizophora sediments, concentrations were maximum in the upper $20 \mathrm{~cm}$, up to $100.0 \mu \mathrm{mol} \cdot \mathrm{L}^{-1}$, and decreased with depth (Figure 5). In the upper layers of the Avicennia and Rhizophora stands, the presence of $\mathrm{Fe}^{3+}, \mathrm{Fe}^{2+}$ and reactive solid iron $\left(\mathrm{Fe}_{\mathrm{ASC}}\right)$ reflects the reduction of iron oxides during $\mathrm{OM}$ decay processes. The absence of $\mathrm{Fe}^{3+}$ and the very low $\mathrm{Fe}^{2+}$ concentrations in the oxic upper layer of the salt-flat may indicate that iron oxide reduction did not occur in these sediments, or that as soon as it produced, $\mathrm{Fe}^{3+}$ precipitated as ferrihydrite and lepidocrocite [44]. Presence of Fe(III) has an influence on sulfur cycling in sediments because it is involved in the oxidation of reduced free sulfide, sulphato-reduction being the main process of OM decomposition in mangroves $[45,46]$. In the three vegetation stands, there is a significant increase in total particulate sulfur below the upper suboxic zone, up to $10 \%$ beneath Avicennia, while free sulfides were only detected in Rhizophora sediments, reaching a maximum value of $3.4 \pm 3.5 \mu \mathrm{mol} \cdot \mathrm{L}^{-1}$ (Figure 5). Concentrations in free dissolved sulfides $\left(\mathrm{H}_{2} \mathrm{~S}+\mathrm{HS}^{-}\right.$ $+\mathrm{S}^{2-}$ ) are usually low in mangrove environment because they are rapidly precipitated as pyrite in presence of dissolved iron [34]. In mangroves, TS is mainly composed of pyrite whose synthesis and stabilization are favored in the most reduced sediment horizons [11]. Noel et al.[44] showed that goethite, the major Fe hosts in the upward horizons of a mangrove developing downstream lateritic soils, progressively disappears with increasing depth, where Fe(II)-bearing pyrite forms, as a result of a sulfate-reduction process. In addition to reduction, intense re-oxidation of aqueous $\mathrm{Fe}(\mathrm{II})$ and Fe-sulfides are suspected, and can lead to the high dissolved iron concentrations as well as to the low measured $\mathrm{pH}$. 
Such process was detected by Noel et al. [44], which results in the formation of ferrihydrite, lepidocrocite and likely goethite in Avicennia and Rhizophora sediments. In addition, these authors found that the relative proportion of a newly formed and poorly ordered iron-oxyhydroxides was higher in the Rhizophora mangrove stand, suggesting that tidal fluctuations may lead to uninterrupted $\mathrm{Fe}$ reduction-oxidation cycles. The closer is the stand to the shore, the more intense are $\mathrm{Fe}$ reduction-oxidation cycles. In addition, concentrations of solid $\mathrm{Fe}$ phases $\left(\mathrm{Fe}_{\mathrm{ASC}}\right.$ and $\left.\mathrm{Fe} \mathrm{HCl}\right)$ decreased from the land-side to the sea-side of the mangrove in this study, confirming Noel et al. [44] hypothesis of a Fe loss from the salt-flat to the Rhizophora stand (i.e., from the land to the shore). The loss of Fe with tides may also explain why dissolved sulfides were only detected in Rhizophora sediments. Those sediments are the richest in organic matter, are not limited in sulfate due to the sea proximity and are characterized by intense sulfide precipitation and dissolution. However dissolved Fe might be exported, and the remaining amount cannot compensate for the production of free dissolved sulfides.
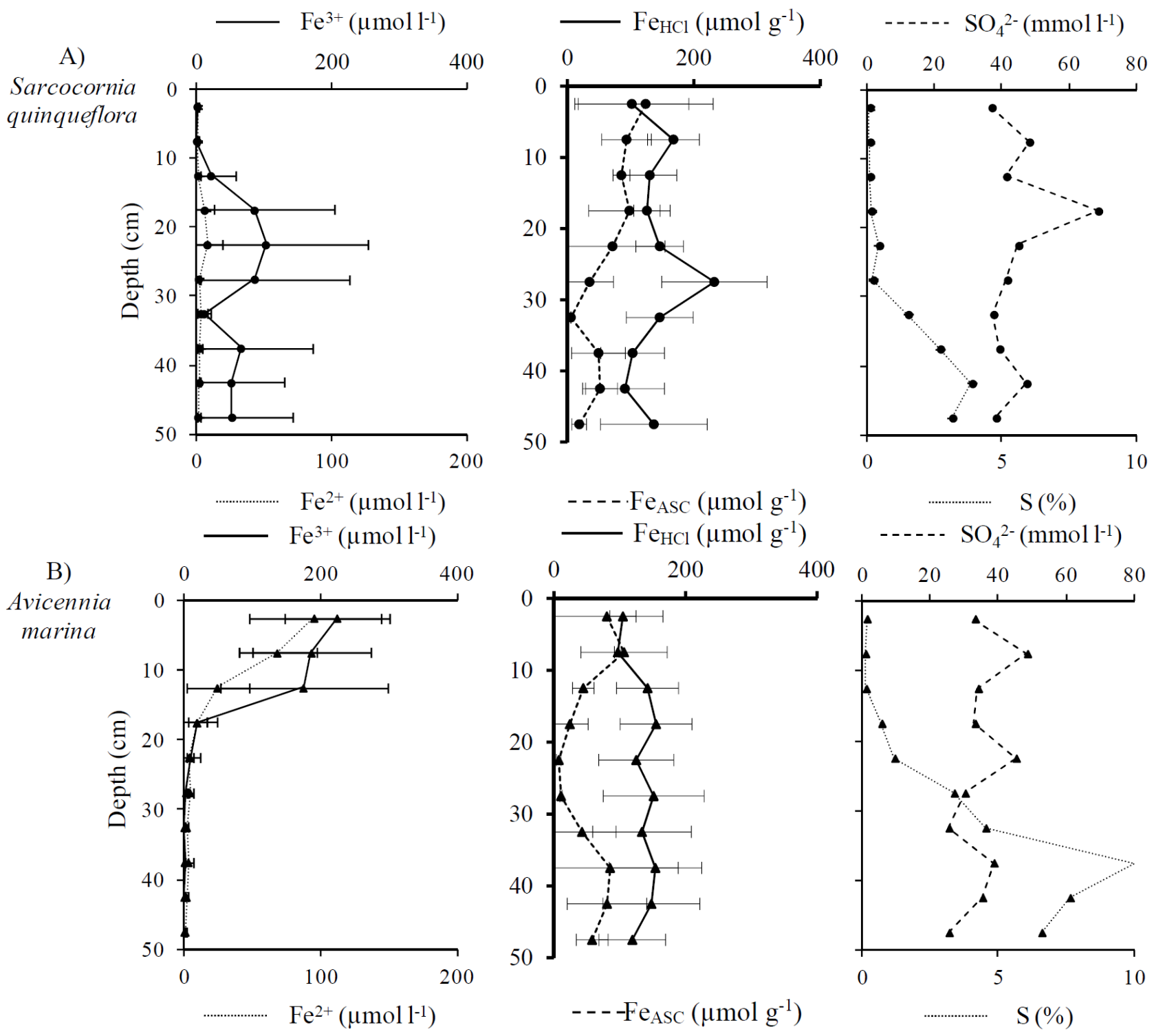

Figure 5. Cont. 


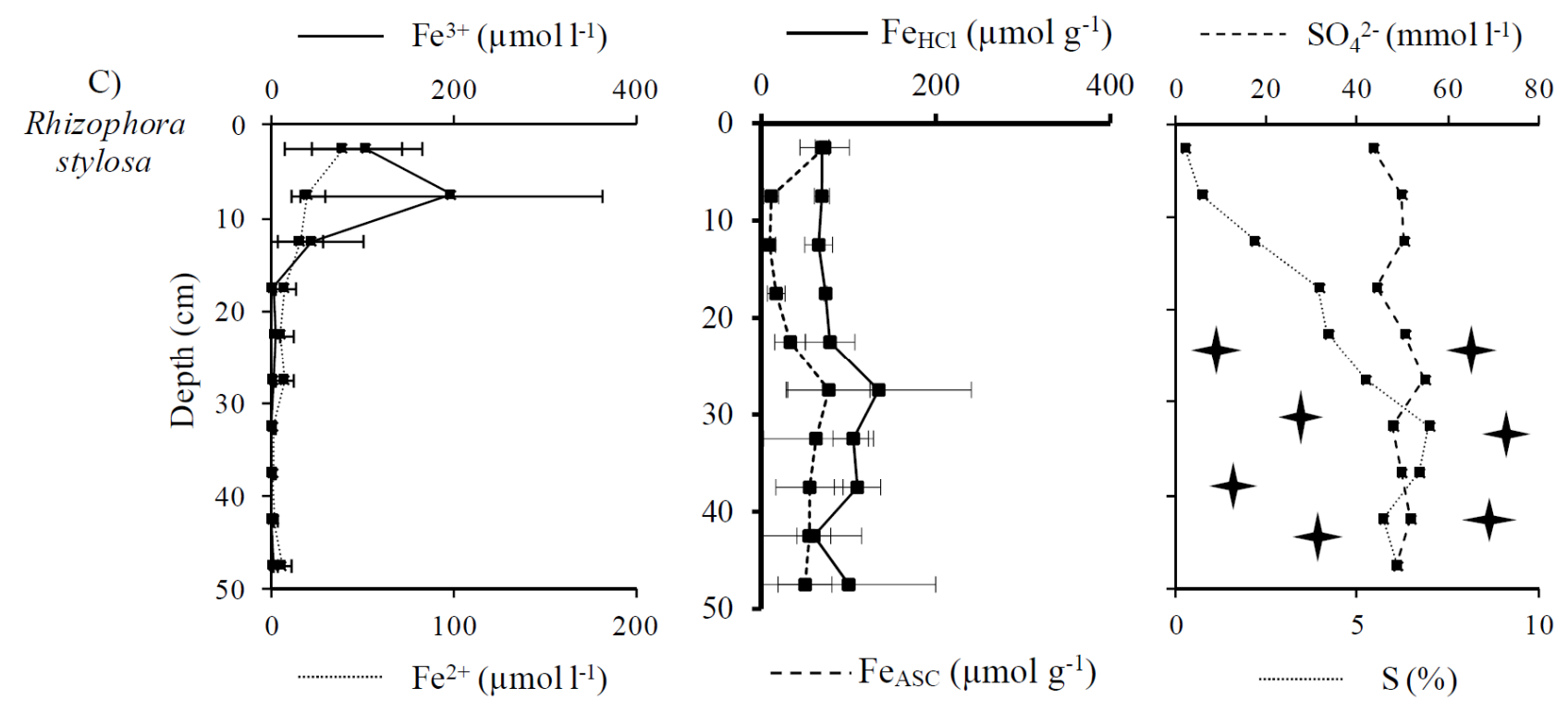

Figure 5. Mean concentrations $(n=3)$ and standard deviation of dissolved iron species $\left(\mathrm{Fe}^{2+}\right.$ and $\left.\mathrm{Fe}^{3+}\right)$, solid iron phases extracted by ascorbate $\left(\mathrm{Fe}_{\mathrm{ASC}}\right)$ and by $\mathrm{HCl} 1 \mathrm{~N}\left(\mathrm{Fe}_{\mathrm{HCl}}\right)$. Concentrations $(n=1)$ in $\mathrm{SO}_{4}{ }^{2-}$ and total particulate sulfur $(\mathrm{S})$ in sediments of the three vegetation stands. Depth where total dissolved sulfide was detected is indicated by stars.

\subsection{Distribution and Speciation of Limited Key Nutrients: Nitrogen and Phosphorus}

Although low $\mathrm{N}$ and $\mathrm{P}$ availabilities, mangroves are a productive ecosystem [47], mainly as a result of the high recycling capacity of the dissolved pool by vascular plants and micro-organisms $[8,48]$. $\mathrm{N}$ and $\mathrm{P}$ limitations may be directly linked to soil elevation and nutrients inputs frequencies by tides or river along the existing zonation [49-51]. Mangrove trees on river banks and on the shoreline can form a strong and dense fringing stand, while mangroves developing at higher elevations usually form dwarf stands [52] as it is the case in New Caledonia.

\subsubsection{Distribution and Speciation of Nitrogen Species along the Mangrove Zonation}

In the three vegetation stands, DON presented the highest concentrations of the whole dissolved nitrogen species, ranging from 20 to $165 \mu \mathrm{mol} \cdot \mathrm{L}^{-1}$ (Figure 6). Despite the differences in productivity and organic accumulation in the sediment between the 3 stands, DON concentrations in their soils were not statistically different. Our study demonstrates that from the land-side to the sea-side of the mangrove, at least in the upper layer, the sediment was characterized by increases in water content, salinity and TOC (Section 3.1). However, at depth in every stands, the sediment was rich of decaying Rhizophora roots from a previous phase of mangrove colonization, resulting in high and homogenous organic content. Alongi et al. [53] suggested that the burial and preservation of a dead root stock and little degradation can be a nutrients conservation process in mangrove soils, and this is probably the case in our studied site. We thus suggest that the stock of decaying Rhizophora roots may have induced the high measured DON concentrations, up to $165.5 \pm 48 \mu \mathrm{mol} \cdot \mathrm{L}^{-1}$. The poorest layer in sedimentary organic carbon, i.e., the upper horizon of the salt-flat, was also the poorest in DON. In addition, this horizon was characterized by the highest redox conditions, as a result of the low organic enrichment and longer 
dry-period, which can favor ammonification and nitrification. DON production from decomposing organic matter may promote bacterial ammonification processes [54]. In fact, in the salt-flat stand, $\mathrm{NH}_{4}{ }^{+}$ accumulates at depth within the organic-rich and anoxic sediments $\left(31.0 \pm 2.1 \mu \mathrm{mol} \cdot \mathrm{L}^{-1}\right.$ at $50 \mathrm{~cm} \mathrm{depth}$, Figure 6). This large amount may result (i) from its production linked to the high organic matter content; (ii) and/or from the absence of a root system that can uptake it; (iii) and/or eventually from possible dissimilatory nitrate reduction to ammonium (DNRA) processes. In some mangroves of New Caledonia, DNRA can account for $10 \%-60 \%$ of total nitrate reduction [55], and favors nitrogen retention, which otherwise would have been denitrified to ammonium. In addition, organic enrichment and production of dissolved sulfides favor DNRA by inhibiting denitrification. In the upper oxic zones, the absence of $\mathrm{NH}_{4}{ }^{+}$may reflects nitrification processes [56]. NOx concentrations were the highest in this layer reaching $4 \mu \mathrm{mol} \cdot \mathrm{L}^{-1}$ (Figure 6). In addition, crab burrows, by increasing the surface area of sediment available for diffusive oxygen exchanges, are privileged sites for nitrification [39,57,58]. Within the vegetated stand, i.e., Avicennia and Rhizophora, $\mathrm{NH}_{4}{ }^{+}$and $\mathrm{NOx}$ concentrations in pore-waters were very low at all depths (Figure 5), probably because they were subject to plant uptake as soon as they were produced. Clough [59]) and Alongi [48] showed that $90 \%$ of the $\mathrm{NH}_{4}{ }^{+}$mangrove consumption is carried through the root system. Vegetated zones are zones of consumption of DIN, which is facilitated by the rapid turnover between producers and consumption.

A)

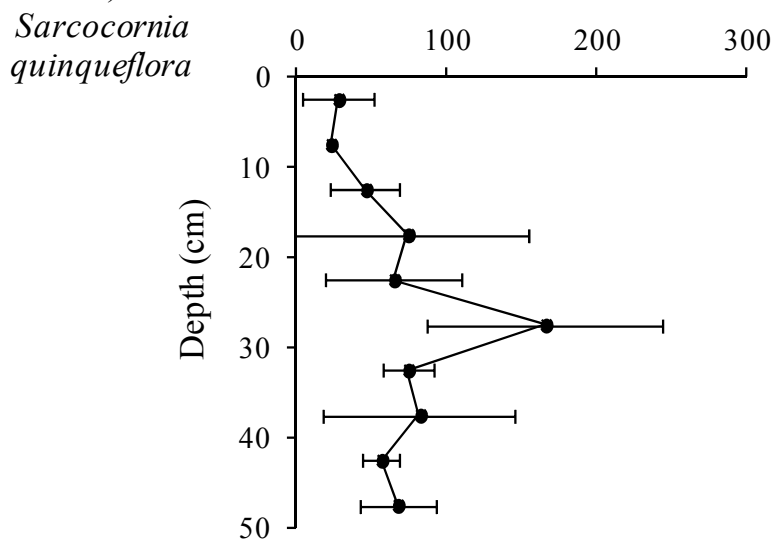

B)

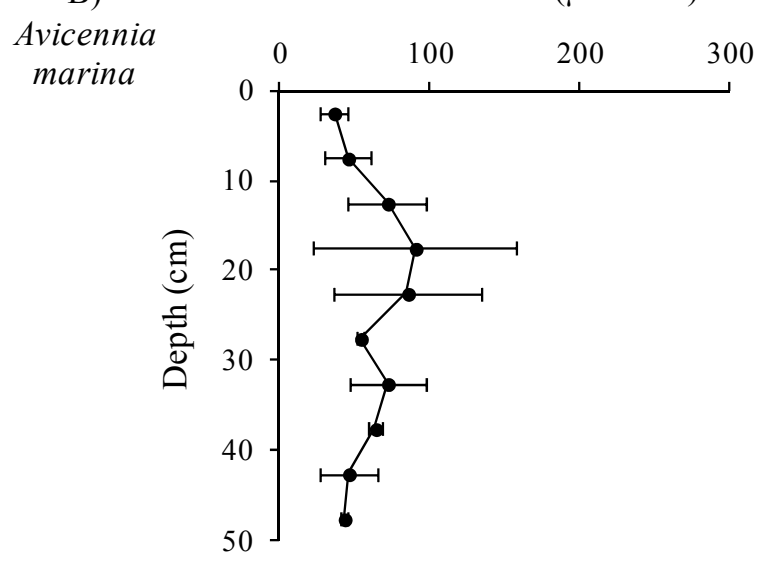

- - -- $\mathrm{NH}_{4}{ }^{+}\left(\mu \mathrm{mol} \mathrm{L}^{-1}\right)$

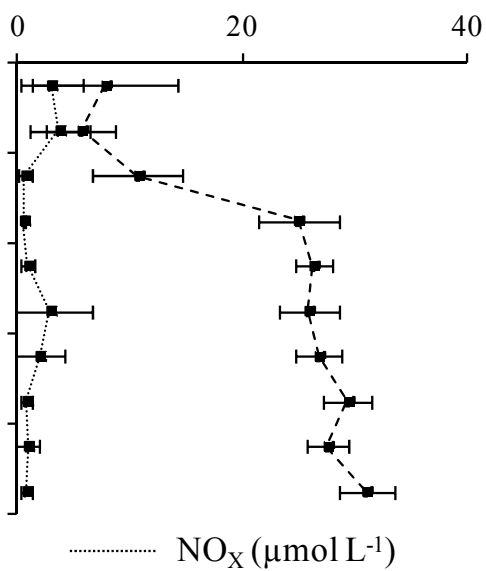

- - - $\mathrm{NH}_{4}^{+}(\mu \mathrm{mol} \mathrm{L}-1)$

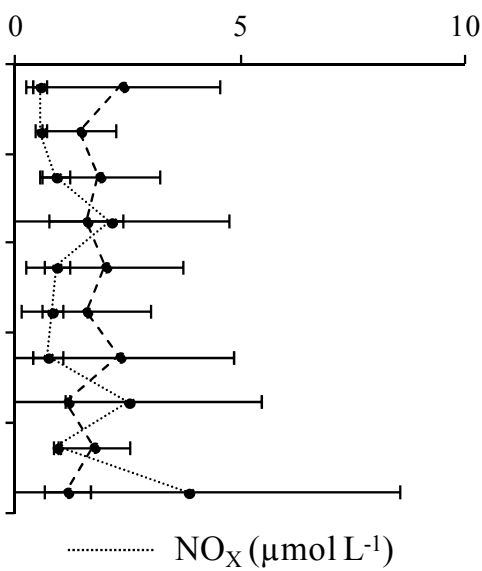

Figure 6. Cont. 
C)

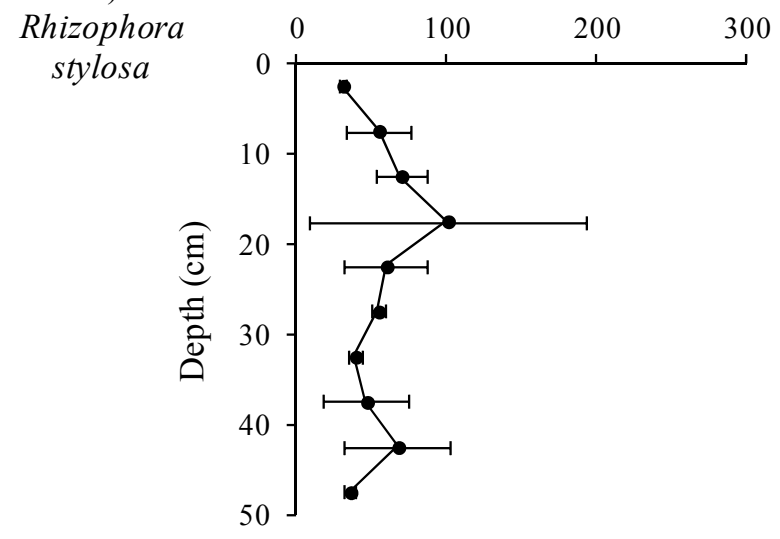

$\mathrm{NH}_{4}^{+}(\mu \mathrm{mol} \mathrm{L}-1)$

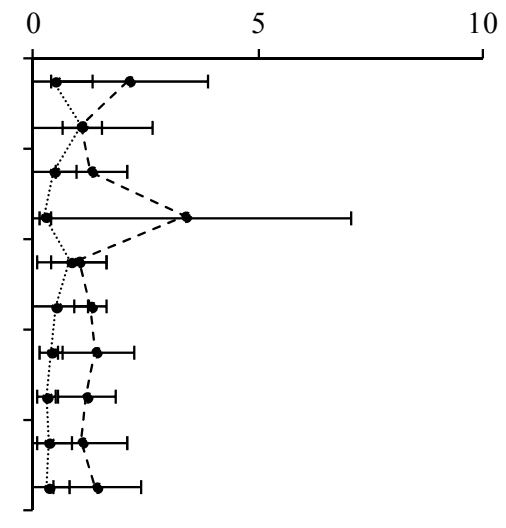

$\mathrm{NO}_{\mathrm{X}}(\mu \mathrm{mol} \mathrm{L}-1)$

Figure 6. Mean concentrations $(n=3)$ and standard deviation of dissolved organic nitrogen (DON), nitrate + nitrite $(\mathrm{NOx})$ and $\mathrm{NH}_{4}{ }^{+}$in sediments of the three vegetation stands. Please note differences in y-axis scales for the $\mathrm{NH}_{4}{ }^{+}$and $\mathrm{NOx}$ between the three vegetation stands.

A)

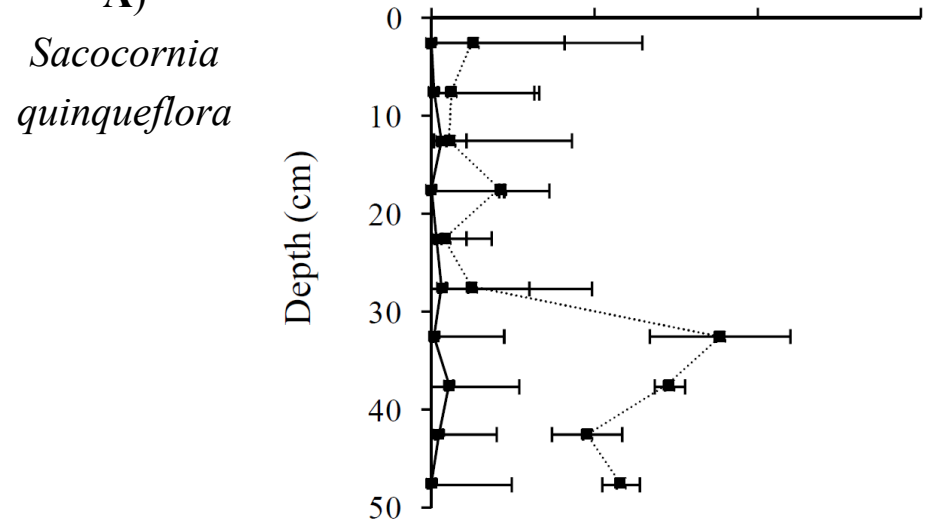

B)

Avicennia marina

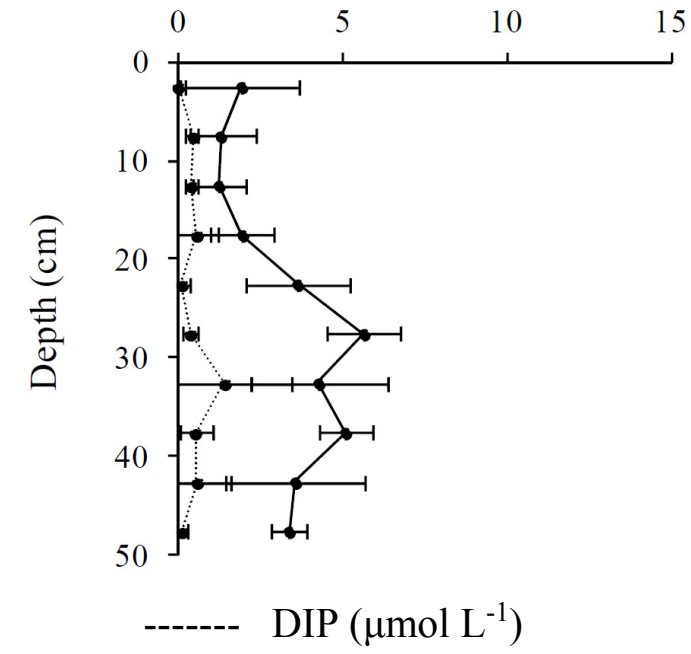

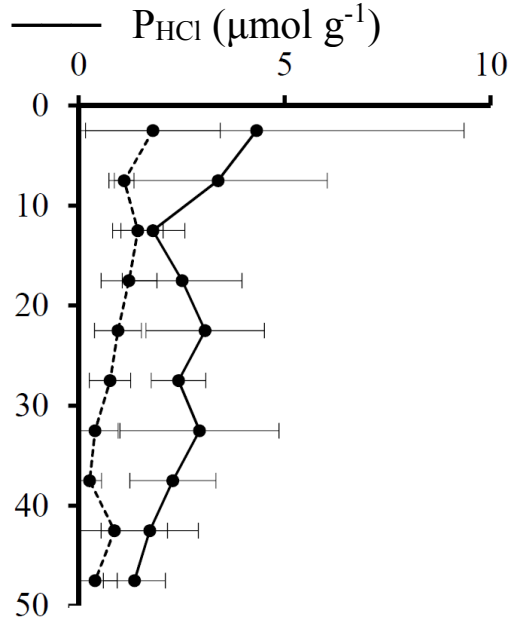

------ PASC $\left(\mu \mathrm{mol} \mathrm{g} \mathrm{g}^{-1}\right)$

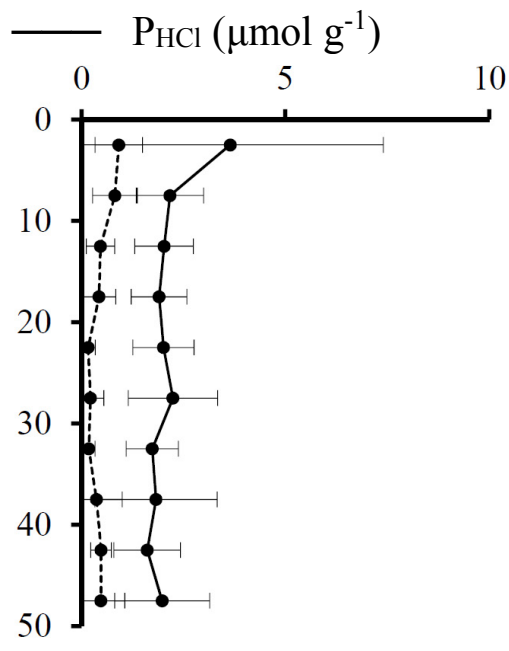

------ $\mathrm{P}_{\mathrm{ASC}}\left(\mu \mathrm{mol} \mathrm{g} \mathrm{g}^{-1}\right)$

Figure 7. Cont. 


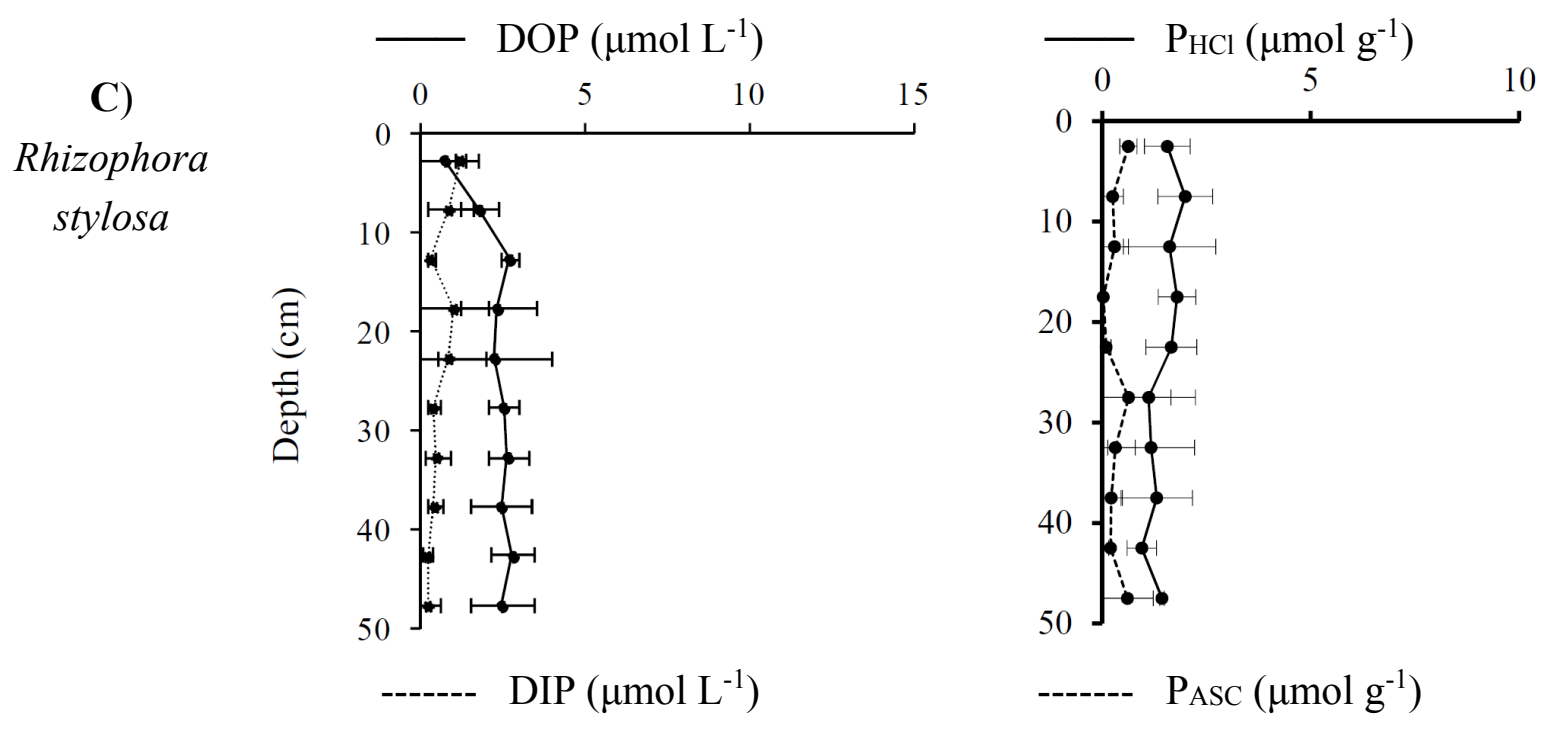

Figure 7. Mean concentrations $(n=3)$ and standard deviation of dissolved organic and inorganic phosphorus (DOP and DIP), and solid phosphorus phases extracted by ascorbate $\left(\mathrm{P}_{\mathrm{ASC}}\right)$ and by $\mathrm{HCl} 1 \mathrm{~N}\left(\mathrm{PHCl}_{\mathrm{HCl}}\right)$ in sediments of the three vegetation stands.

\subsubsection{Distribution and Speciation of Phosphorus Species along the Mangrove Zonation}

The solid fractions of phosphorus $\left(\mathrm{P}_{\mathrm{ASC}}\right.$ and $\left.\mathrm{P}_{\mathrm{HCl}}\right)$ decreased from the land-side to the sea-side of the mangrove (Figure 7). In addition, concentrations decreased with depth, for instance within the salt-flat,

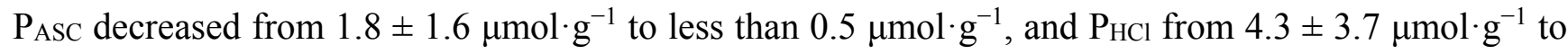
less than $1.5 \mu \mathrm{mol} \cdot \mathrm{g}^{-1}$ (Figure $7 \mathrm{a}$ ). Indeed, iron oxides constitute an enormous trap of inorganic phosphorus in oxic sediment zones, but their dissolution result in quick DIP release in pore-waters. Consequently, we suggest that the decrease of total solid fractions of phosphorus can result from the iron oxide dissolution evidenced earlier. In addition, the total phosphorus decreased from land-side to sea-side, probably also resulted from the process of iron loss due to the gradient of oxidation-reduction processes coupled to increased plant uptake. Dissolved phosphorus concentrations in pore-waters depends both on biological activity (root exudation, bacterial decomposition and uptake by root systems, [60]) and on abiotic factors as adsorption and desorption on iron hydroxides and oxyhydroxides $[32,33,61]$. DOP concentrations were very low beneath each mangrove stand, but increased with depth beneath Avicennia and Rhizophora, up to 5 and $3.0 \mu \mathrm{mol} \cdot \mathrm{L}^{-1}$, respectively, probably as a result of root system development and an increase of root exudates. In pore-waters, the presence of DOP is supplied by root-system exudates and sedimentary OM decomposition (Figure 7). In the upper layer of the salt-flat, the poorly developed root system of Sarcocornia and the low organic accumulation leads to low DOP concentrations $\left(<1 \mu \mathrm{mol} \cdot \mathrm{L}^{-1}\right.$, Figure 7$)$. In parallel, DOP decomposition by bacteria should lead to an increase in DIP concentrations. However, DIP concentrations were low except in the salt-flat, where they increased below $30 \mathrm{~cm}$ depth (Figure 7a). In the anoxic zone of salt-flat, where the uptake by plants is negligible, DIP concentrations increased with depth, up to $8 \mu \mathrm{mol} \cdot \mathrm{L}^{-1}$, and the dissolved $\mathrm{Fe} / \mathrm{P}$ ratio remained low (Table 2). However, according to high values of particulate Fe/P ratios calculated in this zone, $\mathrm{P}$ already appears as a limiting nutrient comparatively to marine sediment where a $\mathrm{Fe} / \mathrm{P}$ ratio about $10 \pm 4$ is evaluated $[33,62]$. In the vegetated mangroves, DIP concentrations remained always very low and the 
ratios $\mathrm{Fe} / \mathrm{P}$ in dissolved phase exceeded 44 in upper sediments colonized by root systems (Table 2). Moreover, $\mathrm{Fe} / \mathrm{P}$ ratios in reactive particulate fraction are twofold higher than those calculated in the salt-flat, highlighting a strong deficit of adsorbed $\mathrm{P}$ onto iron oxides in mangrove stands. This result may evidences that in Avicennia and Rhizophora stands, as soon as DIP is released from iron oxide reduction, there is a fast assimilation by the roots system, which does not exist in the salt-flat area. This process may explain low DIP concentrations in pore-water of the vegetated zone and its accumulation in the salt-flat.

Table 2. Mean $\mathrm{Fe} / \mathrm{P}$ ratios in upper sediments $(0-15 \mathrm{~cm})$ and underlying sediments $(15-50 \mathrm{~cm})$ of the three mangrove vegetation stands. This vertical limit at $15 \mathrm{~cm}$ was chosen as a function of TOC content and redox conditions. The upper layer reflecting a more active layer.

\begin{tabular}{cccccc}
\hline Ratio & Fraction & Depth $(\mathbf{c m})$ & Salt Flat & Avicennia Stand & Rhizophora Stand \\
\hline \multirow{6}{*}{$\mathrm{Fe} / \mathrm{P}$} & $0-15$ & 4 & 94 & 44 \\
& \multirow{2}{*}{ Dissolved inorganic fraction } & $15-50$ & 9 & 20 & 19 \\
\cline { 2 - 6 } & \multirow{2}{*}{ Particulate reactive fraction (Ascorbate) } & $0-15$ & 73 & 121 & 70 \\
\cline { 2 - 6 } & $15-50$ & 79 & 147 & 191 \\
\cline { 2 - 6 } & \multirow{2}{*}{ Particulate amorphous fraction (HCl) } & $0-15$ & 78 & 79 & 50 \\
& $15-50$ & 71 & 77 & 70 \\
\hline
\end{tabular}

\section{Conclusions}

Mangrove zonation, resulting from differences in soil elevation and thus differences in nutrient inputs and soil salinity, leads to specific distribution and speciation of the studied elements, and may regulate the ability of a mangrove ecosystem to be a source or a sink of these compounds. In upstream area, the sediment is frequently emerged, leading to a high rate of evaporation and thus, in high salinities and low pore-water content. In these conditions, only dwarfs' stands develop, which lead to a low organic carbon accumulation in sediment. However, TOC content as well as the contribution of mangrove debris to the organic pool increased towards the sea-side of the mangrove. These increases in TOC and water content led to decreasing redox values towards the sea-side. There were no clear gradients of dissolved inorganic nutrients along the zonation. However, their accumulation in a deep, anoxic, and organic rich layer in the salt-flat evidences their production from the sedimentary organic stock. While their absence in the vegetated zone may result from their rapid uptake by mangrove trees as soon as they are produced. In the three vegetation stands, there is a significant increase in total particulate sulfur below the upper suboxic zone, evidencing iron oxide reduction as well as sulfate-reduction processes. In addition to reduction processes, intense re-oxidation of aqueous $\mathrm{Fe}(\mathrm{II})$ and $\mathrm{Fe}$-sulfides are suspected, leading to the high dissolved iron concentrations as well as low $\mathrm{pH}$. The latter decreased from the land-side to the sea-side as a result on the one hand on the increasing amount of organic matter to be decomposed and, on the other hand on possible sulfide oxidation, due to frequent tidal inundation of Rhizophora stand. Tidal fluctuations may be a major cause for continuous Fe reduction-oxidation cycles, which may be thus more intense when the stand is closer to the shore. Additionally, concentrations of solid phase Fe decreased from the land-side to the sea-side of the mangrove, confirming the hypothesis of a loss of Fe from the salt-flat to the Rhizophora. These increased oxidation-reduction processes from the land to the 
sea may also explain the fact that total phosphorus, of which cycling is strongly linked to iron oxides cycle, decreased along a land-sea gradient in the mangrove. Within a future research effort, concentrations and speciation of $\mathrm{Fe}$ and $\mathrm{P}$ in the dissolved and in the particulate phases in a mangrove tidal creek will be determined as a function of tides to confirm our hypothesis of elements loss towards the coastal area as a result of frequent re-oxidation due to tidal cycles.

\section{Acknowledgments}

The authors gratefully acknowledge the staff of the Saint Vincent shrimp farm, Christophe Canel, and of the IFREMER station for their valuable help and the access to their laboratory. We thank Audrey Leopold for her assistance with field and laboratory works, and Philippe Gerard (Laboratoire de Chimie Marine) from IRD-Nouméa for the chemical analysis. This work was supported by the ZONECO Program, the Northern Province and Southern Province of New Caledonia. The authors are grateful to two anonymous reviewers who critically evaluated this manuscript and provided many useful suggestions that have helped to improve its quality.

\section{Author Contributions}

N.M., L.D.P., C.M. and J.D. performed the field work. N.M. and J.D. performed the chemical analyses. J.D., C.M., and T.M. wrote the manuscript. All authors discussed the results and contributed to the manuscript.

\section{Conflicts of Interest}

The authors declare no conflict of interest.

\section{References}

1. Giri, C.; Ochieng, E.; Tieszen, L.L.; Zhu, Z.; Singh, A.; Loveland, T.; Masek, J.; Duke, N. Status and distribution of mangrove forests of the world using earth observation satellite data. Glob. Ecol. Biogeogr. 2011, 20, 154-159.

2. Duke, N.C.; Meynecke, J.-O.; Dittmann, S.; Ellison, A.M.; Anger, K.; Berger, U.; Cannicci, S.; Diele, K.; Ewel, K.C.; Field, C.D.; et al. A world without mangroves? Science 2007, 317, 41-42.

3. Barbier, E.B. Valuing ecosystem services as productive inputs. Econ. Policy 2007, 22, 177-229.

4. Walters, B.B. Mangrove forests and environmental security. In Forests in the Balance: Linking Tradition and Technology, XXII IUFRO World Congress; Innes, J.I., Edwards, I.K, Wilford, D.J., Eds.; International Foresty Review: Brisbane, Australia, 2006; Volume 7, p. 290.

5. Chmura, G.L.; Anisfeld, S.C.; Cahoon, D.R.; Lynch, J.C. Global carbon sequestration in tidal, saline wetland soils. Glob. Biogeochem. Cycles 2003, 17, 1111.

6. Donato, D.C.; Kauffman, J.B.; Murdiyarso, D.; Kurnianto, S.; Stidham, M.; Kanninen, M. Mangrove among the most carbon-rich forests in the tropics. Nat. Geosci. 2011, 4, 293-297.

7. Kristensen, E.; Bouillon, S.; Dittmar, T.; Marchand, C. Organic carbon dynamics in mangrove ecosystems: A review. Aquat. Bot. 2008, 89, 201-219. 
8. Alongi, D.M.; Clough, B.F.; Robertson, A.I. Nutrient-use efficiency in arid-zone forests of the mangroves rhizophora stylosa and avicennia marina. Aquat. Bot. 2005, 82, 121-131.

9. Alongi, D.M.; Tirendi, F.; Clough, B.F. Below-ground decomposition of organic matter in forests of the mangrove rhizophora stylosa and avicennia marina along the arid coast of western australia. Aquat. Bot. 2000, 68, 97-122.

10. Marchand, C.; Baltzer, F.; Lallier-Vergès, E.; Albéric, P. Pore-water chemistry in mangrove sediments: Relationship with species composition and developmental stages (French Guiana). Mar. Geol. 2004, 208, 361-381.

11. Ferreira, T.O.; Otero, X.L.; Vidal-Torrado, P.; Macías, F. Effects of bioturbation by root and crab activity on iron and sulfur biogeochemistry in mangrove substrate. Geoderma 2007, 142, 36-46.

12. McKee, K.L. Soil physicochemical patterns and mangrove species distribution-Reciprocal effects? J. Ecol. 1993, 81, 477-487.

13. Walsh, G.E. Mangroves: A review. In Ecology of Halophytes; Queen, R.J.R.H., Ed.; Academic Press: Waltham, MA, USA, 1974; pp. 51-174.

14. Ellison, J.C. Impacts of sediment burial on mangroves. Mar. Pollut. Bull. 1999, 37, 420-426.

15. Clark, M.W.; McConchie, D.; Lewis, D.W.; Saenger, P. Redox stratification and heavy metal partitioning in avicennia-dominated mangrove sediments: A geochemical model. Chem. Geol. 1998, 149, 147-171.

16. Virly, S. Atlas des mangroves de nouvelle-calédonie. In Typologies et Biodiversité des Mangroves de Nouvelle-Calédonie; ZoNéCo: Nouméa, New Caledonia, 2006; p. 213.

17. Marchand, C.; Allenbach, M.; Lallier-Vergès, E. Relationships between heavy metals distribution and organic matter cycling in mangrove sediments (conception bay, New Caledonia). Geoderma 2011, 160, 444-456.

18. Marchand, C.; Fernandez, J.M.; Moreton, B.; Landi, L.; Lallier-Vergès, E.; Baltzer, F. The partitioning of transitional metals (Fe, Mn, Ni, Cr) in mangrove sediments downstream of a ferralitized ultramafic watershed (New Caledonia). Chem. Geol. 2012, 300-301, 70-80.

19. Baltzer, F. Géodynamique de la sédimentation et diagenèse précoce en domaine ultrabasique - Nouvelle calédonie. Trav. Doc. ORSTOM 1982, 152, 283.

20. Song, J.; Luo, Y.M.; Zhao, Q.G.; Christie, P. Novel use of soil moisture samplers for studies on anaerobic ammonium fluxes across lake sediment-water interfaces. Chemosphere 2003, 50, 711-715.

21. Marchand, C.; Lallier-Vergès, E.; Baltzer, F.; Albéric, P.; Cossa, D.; Baillif, P. Heavy metals distribution in mangrove sediments along the mobile coastline of French Guiana. Mar. Chem. 2006, 98, 1-17.

22. Vismann, B. Sulphide exposure experiments: The sulphide electrode and a set-up automatically controlling sulphide, oxygen and pH. J. Exp. Mar. Biol. Ecol. 1996, 204, 131-140.

23. Stookey, L.L. Ferrozine-A new spectrophotometric reagent for iron. Anal.Chim. Acta 1970, 42, 779-781.

24. Strickland, J.D.H.; Parsons, T.R. A Practical Handbook of Seawater Analysis; Fisheries Research Board of Canada: Ottawa, Ontario, Canada, 1972; Volume 197.

25. Rodier, J. L'analyse de L'eau, Eaux Naturelles, Eaux Résiduaires, Eau de Mer; Dunod: Paris, France, 1976; p. 364. 
26. Holmes, R.M.; Aminot, A.; Kérouel, R.; Hooker, B.A.; Peterson, B.J. A simple and precise method for measuring ammonium in marine and freshwater ecosystems. Can. J. Fish. Aquat. Sci. 1999, 56, 1801-1808.

27. Bendschneider, K.; Robinson, R.J. A new spectrophotometric method for the determination of nitrite in sea water. J. Mar. Res. 1952, 11, 87-96.

28. Murphy, J.; Riley, J.P. A modified single solution method for determination of phosphate in natural waters. Anal. Chim. Acta 1962, 26, 31-36.

29. Raimbault, P.; Pouvesle, W.; Diaz, F.; Garcia, N.; Sempéré, R. Wet-oxidation and automated colorimetry for simultaneous determination of organic carbon, nitrogen and phosphorus dissolved in seawater. Mar. Chem. 1999, 66, 161-169.

30. Marchand, C.; Lallier-Vergès, E.; Disnar, J.R.; Kéravis, D. Organic carbon sources and transformations in mangrove sediments: A rock-eval pyrolysis approach. Org. Geochem. 2008, 39, 408-421.

31. Lafargue, E.; Marquis, F.; Pillot, D. Rock-eval 6 applications in hydrocarbon exploration, production and soil contamination studies. Rev. Inst. Fr. Pét. 1998, 53, 421-437.

32. Deborde, J.; Anschutz, P.; Chaillou, G.; Etcheber, H.; Commarieu, M.V.; Lecroart, P.; Abril, G. The dynamics of phosphorus in turbid estuarine systems: Example of the gironde estuary (France). Limnol. Oceanogr. 2007, 52, 862-872.

33. Anschutz, P.; Zhong, S.; Sundby, B.; Mucci, A.; Gobeil, C. Burial efficiency of phosphorus and the geochemistry of iron in continental margin sediments. Limnol. Oceanogr. 1998, 43, 53-64.

34. Kostka, J.E.; Luther III, G.W. Partitioning and speciation of solid phase iron in saltmarsh sediments. Geochim. Cosmochim. Acta 1994, 58, 1701-1710.

35. Anschutz, P.; Chaillou, G.; Lecroart, P. Phosphorus diagenesis in sediment of the thau lagoon. Estuar. Coast. Shelf Sci. 2007, 72, 447-456.

36. Bouillon, S.; Dahdouh-Guebas, F.; Rao, A.V.V.S.; Koedam, N.; Dehairs, F. Sources of organic carbon in mangrove sediments: Variability and possible ecological implications. Hydrobiologia 2003, 495, 33-39.

37. Marchand, C.; Disnar, J.R.; Lallier-Vergès, E.; Lottier, N. Early diagenesis of carbohydrates and lignin in mangrove sediments subject to variable redox conditions (French Guiana). Geochim. Cosmochim. Acta 2005, 69, 131-142.

38. Lallier-Vergès, E.; Marchand, C.; Disnar, J.R.; Lottier, N. Origin and diagenesis of lignin and carbohydrates in mangrove sediments of guadeloupe (French West Indies): Evidence for a two-step evolution of organic deposits. Chem. Geol. 2008, 255, 388-398.

39. Botto, F.; Iribarne, O. Contrasting effects of two burrowing crabs (Chasmagnathus granulata and Uca uruguayensis) on sediment composition and transport in estuarine environments. Estuar. Coast. Shelf Sci. 2000, 51, 141-151.

40. Nielsen, T.; Andersen, F.Ø. Phosphorus dynamics during decomposition of mangrove (Rhizophora apiculata) leaves in sediments. J. Exp. Mar. Biol. Ecol. 2003, 293, 73-88.

41. Thibodeau, F.R.; Nickerson, N.H. Differential oxidation of mangrove substrate by Avicennia germinans and Rhizophora mangle. Am. J. Bot. 1986, 73, 512-516. 
42. Dublet, G.; Juillot, F.; Morin, G.; Fritsch, E.; Fandeur, D.; Ona-Nguema, G.; Brown, G.E., Jr. Ni speciation in a new caledonian lateritic regolith: A quantitative $\mathrm{x}$-ray absorption spectroscopy investigation. Geochim. Cosmochim. Acta 2012, 95, 119-133.

43. Fernandez, J.-M.; Ouillon, S.; Chevillon, C.; Douillet, P.; Fichez, R.; Gendre, R.L. A combined modelling and geochemical study of the fate of terrigenous inputs from mixed natural and mining sources in a coral reef lagoon (New Caledonia). Mar. Pollut. Bull. 2006, 52, 320-331.

44. Noël, V.; Marchand, C.; Juillot, F.; Ona-Nguema, G.; Viollier, E.; Marakovic, G.; Olivi, L.; Delbes, L.; Gelebart, F.; Morin, G. Exafs analysis of iron cycling in mangrove sediments downstream a lateritized ultramafic watershed (Vavouto Bay, New Caledonia). Geochim. Cosmochim. Acta 2014, 136, 211-228.

45. Canfield, D.E.; Raiswell, R.; Bottrell, S.H. The reactivity of sedimentary iron minerals toward sulfide. Am. J. Sci. 1992, 292, 659-683.

46. Holmer, M.; Kristensen, E.; Banta, G.; Hansen, K.; Jensen, M.H.; Bussawarit, N. Biogeochemical cycling of sulfur and iron in sediments of a south-east asian mangrove, phuket island, thailand. Bioelectrochemistry 1994, 26, 145-161.

47. Bouillon, S.; Borges, A.V.; Castañeda-Moya, E.; Diele, K.; Dittmar, T.; Duke, N.C.; Kristensen, E.; Lee, S.Y.; Marchand, C.; Middelburg, J.J.; et al. Mangrove production and carbon sinks: A revision of global budget estimates. Glob. Biogeochem. Cycles 2008, 22, GB2013.

48. Alongi, D.M. The dynamics of benthic nutrient pools and fluxes in tropical mangrove forests. J. Mar. Res. 1996, 54, 123-148.

49. Feller, I.C.; Lovelock, C.; Mckee, K.L. Nutrient addition differentially affects ecological processes of avicennia germinans in nitrogen versus phosphorus limited mangrove ecosystems. Ecosystems 2007, 10, 347-359.

50. Feller, I.C. Effects of nutient enrichment on growth and herbivory of dwarf red mangrove (Rhizophora mangle). Ecol. Monogr. 1995, 65, 477-505.

51. Lovelock, C.E.; Feller, I.C.; McKee, K.L.; Engelbrecht, B.M.J.; MC., B. The effect of nutrient enrichment on growth, photosynthesis and hydraulic conductance of dwarf mangroves in Panama. Funct. Ecol. 2004, 18, 25-33.

52. Dangremond, E.M.; Feller, I.C. Functional traits and nutrient limitation in the rare mangrove pelliciera rhizophorae. Aquat. Bot. 2014, 116, 1-7.

53. Alongi, D.M.; Trott, L.A.; Wattayakorn, G.; Clough, B.F. Below ground nitrogen cycling in relation to net canopy production in mangrove forests of Southern Thailand. Mar. Biol. 2002, 140, 855-864.

54. Badr, E.-S.A.; Tappin, A.D.; Achterberg, E.P. Distributions and seasonal variability of dissolved organic nitrogen in two estuaries in sw england. Mar. Chem. 2008, 110, 153-164.

55. Molnar, N.; Welsh, D.T.; Marchand, C.; Deborde, J.; Meziane, T. Impacts of shrimp farm effluent on water quality, benthic metabolism and n-dynamics in a mangrove forest (New Caledonia). Estuar. Coast. Shelf Sci. 2013, 117, 12-21.

56. Canfield, D. Organic matter oxidation in marine sediments. In Interactions of $C, N, P$ and $S$ Biogeochemical Cycles and Global Change; Wollast, R.; Mackenzie, F.; Chou, L., Eds.; Springer Berlin Heidelberg: Berlin, Germany, 1993; Volume 4, pp. 333-363. 
57. Kristensen, E.; Alongi, D.M. Control by fiddler crabs (Uca vocans) and plant roots (Avicennia marina) on carbon, iron, and sulfur biogeochemistry in mangrove sediment. Limnol. Oceanogr. 2006, 51, 1557-1571.

58. Jordan, M.A.; Welsh, D.T.; Dunn, R.J.K.; Teasdale, P.R. Influence of trypaea australiensis population density on benthic metabolism and nitrogen dynamics in sandy estuarine sediment: A mesocosm simulation. J. Sea Res. 2009, 61, 144-152.

59. Clough, B.F. Primary productivity and growth of mangrove forests. In Tropical Mangrove Ecosystems; Robertson, A.I., Alongi, D.M., Eds.; American Geophysical Union: Washington, DC, USA, 1992; Volume Coastal and Estuarine Study No.41, pp. 225-250.

60. Gleason, S.M.; Ewel, K.C.; Hue, N. Soil redox conditions and plant-soil relationships in a micronesian mangrove forest. Estuar. Coast. Shelf Sci. 2003, 56, 1065-1074.

61. Jensen, H.S.; Mortensen, P.B.; Andersen, F.Ø.; Rasmussen, E. Phosphorus cycling in coastal marine sediment, Aarhus Bay, Denmark. Mar. Ecol. Prog. Ser. 1995, 293, 49-58.

62. Cha, H.J.; Lee, C.B.; Kim, B.S.; Choi, M.S.; Ruttenberg, K.C. Early diagenetic redistribution and burial of phosphorus in the sediments of the southwestern East Sea (Japan Sea). Mar. Geol. 2005, $216,127-143$.

(C) 2015 by the authors; licensee MDPI, Basel, Switzerland. This article is an open access article distributed under the terms and conditions of the Creative Commons Attribution license (http://creativecommons.org/licenses/by/4.0/). 